\title{
Produksi Asam Laktat dari Fermentasi Limbah Cair Olahan Kelapa dengan Variasi Konsentrasi Inokulum Lactobacillus acidophilus
}

\author{
Ratna $^{1}$, Ulfa Triovanta ${ }^{2}$, Darwin $^{3}$ \\ ${ }^{1,2,3}$ Program Studi Teknik Pertanian, Fakultas Pertanian, Universitas Syiah Kuala, Banda Aceh \\ *Koresponden email: ratna@unsyiah.ac.id
}

Diterima: 22 September 2020

Disetujui: 13 Oktober 2020

\begin{abstract}
The aim of this research is to study the fermentation technique of coconut processed liquid waste by varying the inoculum concentration of Lactobacillus acidophilus bacteria for lactic acid production. This research was carried out in several steps, namely the first step was the inoculum cultivation process of Lactobacillus acidophilus bacteria, the second step was the fermentation process of coconut water with variations in the concentration of Lactobacillus acidophilus bacteria inoculum, namely 5\%, 10\% and $20 \%$. Analysis of lactic acid products, pH, glucose, Total Dissolved Solid (TDS), Total Suspended Solid (TSS) and Volatile Suspended Solid (VSS). The variation in the concentration of Lactobacillus acidophilus bacteria inoculum $20 \%$ is the most optimum to produce total lactic acid for batch and continuous systems. The results of the correlation analysis for inoculum variations of 5\%, $10 \%$ and $20 \%$ had a strong relationship with lactic acid production, decreased $\mathrm{pH}$ and decreased glucose levels. The greater the inoculum concentration, the greater the decrease in the TDS, TSS and VSS content.
\end{abstract}

Keywords: batch system, coconut water, fermentation, continuous system, total lactic acid

\section{Abstrak}

Tujuan dari penelitian ini yaitu untuk mengkaji teknik fermentasi limbah cair olahan kelapa dengan menvariasikan konsentrasi inokulum bakteri Lactobacillus acidophilus untuk produksi asam laktat. Penelitian ini dilakukan dengan beberapa langkah yaitu langkah yang pertama dilakukan proses kultivasi inoculum bakteri Lactobacillus acidophilus, langkah yang kedua dilakukan proses fermentasi air kelapa dengan variasi konsentrasi inoculum bakteri Lactobacillus acidophilus yaitu 5\%, 10\% dan 20\%. Analisis terhadap produk asam laktat, nilai $\mathrm{pH}$, glukosa, Total Dissolved Solid (TDS), Total Suspended Solid (TSS) dan Volatile Suspended Solid (VSS). Variasi konsentrasi inokulum bakteri Lactobacillus acidophilus 20\% merupakan yang paling optimum menghasilkan total asam laktat untuk sistem batch maupun continuous. Hasil analisis korelasi untuk variasi inokulum 5\%, 10\% dan 20\% memiliki hubungan yang kuat terhadap produksi asam laktat, penurunan nilai $\mathrm{pH}$ dan penurunan kadar glukosa. Semakin besar konsentrasi inokulum semakin besar pula penurunan kandungan TDS, TSS dan VSS.

Kata Kunci: air kelapa, lactobacillus acidophilus, fermentasi, sistem batch, sistem continuous, total asam laktat

\section{Pendahuluan}

Kelapa adalah salah satu tanaman yang menghasilkan buah dengan berbagai macam manfaatnya. Salah satu bahagian kelapa yang paling banyak dimanfaatkan adalah buah kelapa. Buah kelapa mulai dari kulit, batok, daging dan air semuanya dapat dimanfaatkan. Jadi, tidak ada bahagian buah kelapa yang akan terbuang sia-sia. Namun dalam prakteknya, pada proses pengolahan buah kelapa yang diambil santannya atau diolah menjadi kopra bahagian yang sering terbuang adalah air kelapanya. Padahal, air kelapa mengandung nutrisi yang sangat bermanfaat. Air dari buah kelapa banyak mengandung karbohidrat, asam amino dan juga vitamin serta mineral-mineral lainnya. Mengingat begitu lengkapnya nutrisi yang dikandung oleh air kelapa maka sangat berpotensi untuk dijadikan sebagai bahan baku indutri pertanian. Salah satu olahan indutri pertanian yang dapat dimanfaatkan dari limbah cair olahan kelapa adalah air kelapa yang diolah melalui proses fermentasi [1].

Proses fermentasi limbah cair olahan kelapa akan menghasilkan asam laktat. Untuk mendapatkan asam laktat dengan rendemen seperti yang diharapkan maka teknik fermentasi dan yang memicu mempercepat proses fermentasi dalam menghasilkan asam laktat harus diperhatikan. Karena salah satu asam organik yang banyak dibutuhkan adalah lactic acid. Ref [2] mengatakan bahwa asam laktat dapat 
dihasil oleh bakteri Lactobacillus. Salah satu bakteri Lactobacillus yang menghasilkan asam laktat adalah Lactobacillus acidophilus. Ref [3] menambahkan bahwa bakteri Lactobacillus acidophilus ini merupakan bakteri yang paling diminati oleh industri fermentasi. Bakteri ini juga sangat menyukai lingkungan yang tinggi kadar gulanya. Karena pada proses fermentasi bahan dasar yang harus ada adalah gula. Produk hasil dari proses fermentasi akan memiliki keunggulan yaitu meningkatnya cita rasa, meningkatnya daya simpan, memperbaiki dan menciptakan tekstur yang baru dan dapat meningkatkan cita rasa dan aroma [4].

Berdasarkan potensi yang dimiliki oleh limbah cair olahan kelapa maka penulis terinsipirasi untuk meneliti air kelapa sebagai bahan baku untuk produksi asam laktat melalui proses fermentasi. Dengan demikian air kelapa yang tadinya terbuang begitu saja dapat dimanfaatkan untuk dijadikan produk yang bernilai ekonomis. Adapun tujuan dari penelitian ini yaitu untuk mempelajari teknik fermentasi limbah cair olahan kelapa dengan menvariasikan konsentrasi inokulum bakteri penghasil asam laktat yaitu Lactobacillus acidophilus.

\section{Metode Penelitian Alat dan Bahan}

Adapun peralatan yang dipakai dalam penelitian ini adalah alat pH meter, TDS meter, glucometer, thermometer, aquarium heater, timbangan analitik, kertas saring, gelas beker, gelas erlemeyer, gelas ukur burette, bioreactor, oven, furnace, saringan dan tisu. Adapun bahan yang dipakai pada penelitian ini adalah limbah air kelapa, bakteri Lactobacillus acidophilus, $\mathrm{pH}$ buffer, glukosa, aquades, $\mathrm{NaOH}$ dan $\mathrm{HCl}$. Prosedur

Adapun langkah-langkah yang ditempuh dalam penelitian ini yaitu langkah pertama untuk kultivasi bakteri dan langkah ke dua untuk proses fermentasi dengan menvariasikan konsentrasi bakteri Lactobacillus acidophilus pada dua teknik fermentasi yaitu fermentasi dengan sistem batch dan continuous dengan kondisi non-sterile dan mesophilic $\left(\mathrm{T}=35^{\circ} \mathrm{C}\right)$, dan langkah yang ke tiga analisis hasil fermentasi (asam laktat).

\section{Kultivasi Bakteri}

Kultivasi Lactobacillus acidophilus dilakukan dengan cara memasukkan Lactobacillus acidophilus ke dalam air kelapa sebagai substrat atau media biakannya. Kultivasi Lactobacillus acidophilus dilakukan dengan sistem fed batch dalam kondisi anaerob. Air kelapa sebanyak $100 \mathrm{ml}$ diinokulasikan dengan Lactobacillus acidophilus dengan konsentrasi 10\%. Setiap 24 jam sekali dilakukan penambahan substrat hingga $\mathrm{pH}$ air kelapa menurun sesuai dengan $\mathrm{pH}$ asam laktat yakni 3,86. Kondisi lingkungan yang optimum untuk pertumbuhan Lactobacillus acidophilus, yaitu dengan suhu berkisar antara $35-38{ }^{\circ} \mathrm{C}$ dan pH 5,5-6,0. Konsentrasi inoculum bakteri Lactobacillus acidophilus, yaitu inokulum 5\% (I1), inokulum $10 \%$ (I2) dan inokulum 20\% (I3).

\section{Proses Fermentasi}

Adapun penelitian ini dilakukan proses fermentasi dengan menvariasikan konsentrasi inoculum bakteri Lactobacillus acidophilus dengan dua Teknik fermentasi yaitu system batch dan semi continuous dengan parameter yang dianalisis yaitu Total Asam Laktat [5], Derajat Keasaman (pH) [5], Kadar Glukosa [6], Total Suspended Solid (TSS) [7][8], Volatile Suspended Solid [7][8], Total Dissolved Solid (TDS) [9].

\section{a. Fermentasi sistem batch}

Sebelum proses fermentasi dimulai, dilakukan analisis terlebih dahulu terhadap air kelapa yang akan digunakan sebagai media atau substrat, yaitu analisis kadar glukosa dan $\mathrm{pH}$. Proses fermentasi dimulai dengan mempersiapkan 3 buah reactor yang berkapasitas 1 L. Selanjutnya air kelapa dinokulasikan dengan Lactobacillus acidophilus dengan konsentrasi masing-masing reactor yaitu I1= $5 \%, \mathrm{I} 2=10 \%$ dan $\mathrm{I} 3=20 \%$. Kemudian reactor tersebut ditutup rapat hingga tidak ada udara yang masuk pada reactor tersebut. Proses fermentasi dilakukan dengan kondisi mesophilic $\left(\mathrm{T}=35^{\circ} \mathrm{C}\right)$. Dilakukan pengambilan sampel setiap 1 jam sekali sebanyak $40 \mathrm{ml}$ untuk dilakukan analisis. 


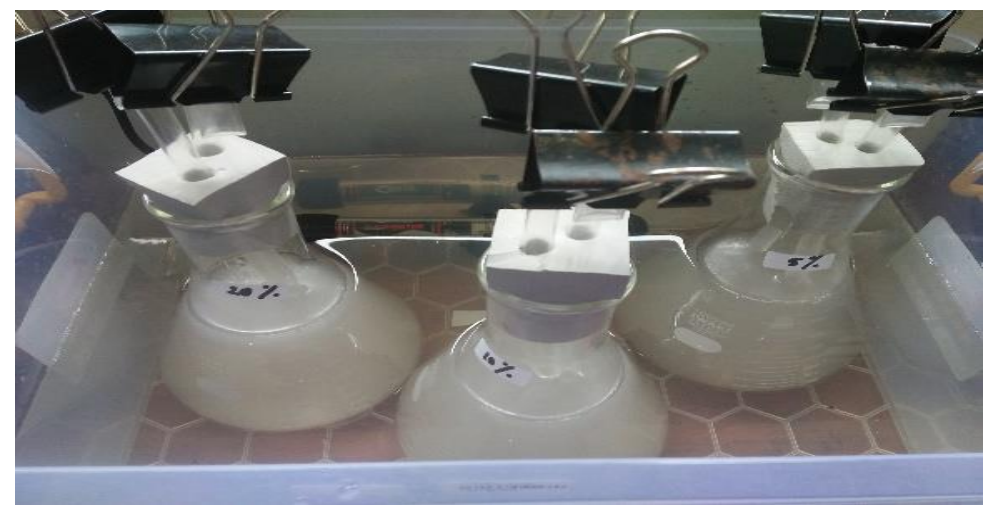

Gambar 1. Proses fermentasi air kelapa dengan sistem batch

\section{b. Fermentasi sistem continuous}

Sebelum proses fermentasi dimulai, dilakukan analisis terlebih dahulu terhadap air kelapa yang akan digunakan sebagai media atau substrat, yaitu analisis kadar glukosa dan $\mathrm{pH}$. Fermentasi dimulai dengan mempersiapkan 3 buah reactor dengan volume $3 \mathrm{~L}$. Berbeda dengan reaktor yang digunakan pada sistem batch, reaktor yang digunakan pada sisitem continuous ini memiliki pengaduk didalamnya yang berputar dengan kecepatan 84,7 rpm.

Fermentasi dimulai dengan menginokulasikan air kelapa dengan Lactobacillus acidophilus dengan konsentrasi masing-masing reactor yaitu $\mathrm{I} 1=5 \%, \mathrm{I} 2=10 \%$ dan $\mathrm{I} 3=20 \%$. Proses fermentasi ini dilakukan dengan mempertahankan suhu pada $35^{\circ} \mathrm{C}$ dan dengan Hydraulic Retention Time (HRT) 10 hari. HRT adalah waktu yang dihitung dari substrat yang tetap berada pada digester sampai habis. Perhitungan yaitu perbandingan volume reaktor $(\mathrm{V})$ dengan volume air kelapa yang ditambahkan setiap hari dengan satuannya adalah hari, dengan rumusnya yaitu $\mathrm{HRT}_{\text {(hari) }}=\mathrm{V} / \mathrm{F}$ [10]. Pada penelitian ini, volume reaktor (V) adalah $3000 \mathrm{ml}$ dan air kelapa yang ditambahkan setiap harinya adalah $300 \mathrm{ml}$ sehingga HRT pada penelitian ini adalah 10 hari.

Pada hari ke 0 fermentasi dilakukan pengambilan sampel hasil fermentasi sebanyak $300 \mathrm{ml}$ untuk dilakukan analisis dan kemudian dimasukkan air kelapa baru ke dalam reactor juga sebanyak $300 \mathrm{ml}$. Pada hari ke 1 fermentasi dilakukan pengambilan sampel hasil fermentasi sebanyak $300 \mathrm{ml}$ untuk dilakukan analisis dan kemudian dimasukkan lagi air kelapa baru ke dalam reactor juga sebanyak $300 \mathrm{ml}$, sehingga volume air kelapa di dalam reaktor tetap $3 \mathrm{~L}$ dan begitu pula pada hari-hari berikutnya.

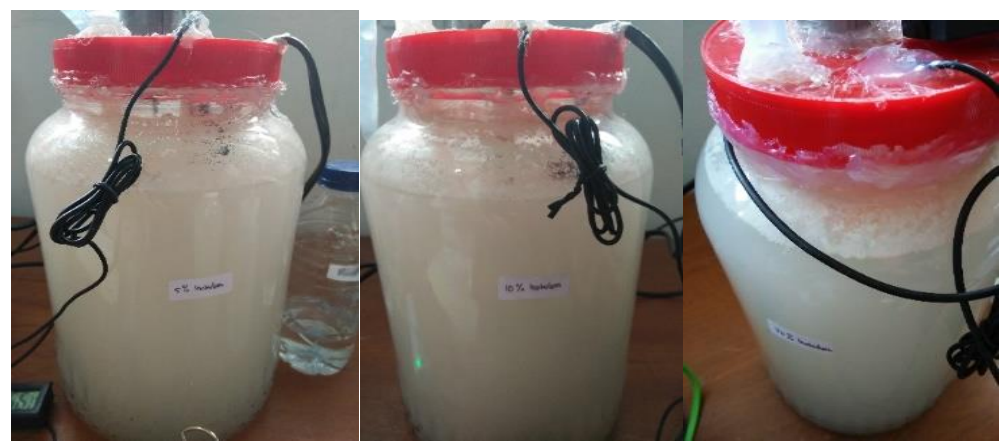

Gambar 2. Proses fermentasi air kelapa dengan sistem continuous

\section{c. Data Analysis}

Perlakuan pada penelitian ini yaitu variasi kosentrasi inoculum dengan tiga taraf yaitu inokulum bakteri Lactobacillus acidophilus 5\% (I1), inoculum bakteri Lactobacillus acidophilus $10 \%$ (I2) dan inoculum bakteri Lactobacillus acidophilus 20\% (I3) dan lama fermentasi dan masing-masing difermentasi dengan sistem batch dan continuous. Data yang diperoleh dianalisis statistik menggunakan regresi linier dan untuk melihat hubungan antar parameter dilakukan analisis koefisien korelasi.

\section{Hasil dan Pembahasan Produk Asam Laktat}

Hasil analisis asam laktat yang diperoleh dari variasi konsentrasi inoculum bakteri Lactobacillus acidophilus pada proses fermentasi limbah air kelapa menggunakan sistem batch dan continuous 
meningkat seiring meningkatnya konsentrasi inokulum bakteri Lactobacillus acidophilus dan lama waktu fermentasi, seperti diperlihatkan pada Gambar 3. Total asam laktat yang diperoleh dari fermentasi sistem batch menunjukkan adanya peningkatan selama proses fermentasi. Pada fermentasi dengan konsentrasi inokulum 5\%, total asam laktat tertinggi diperoleh pada jam ke 7-10 fermentasi, yaitu sebesar 0,135\%. Pada fermentasi dengan konsentrasi inokulum 10\%, total asam laktat tertinggi diperoleh pada jam ke 9-11 fermentasi, yaitu sebesar 0,149\% dan konsentrasi inokulum bakteri Lactobacillus acidophilus 20\%, total asam laktat tertinggi diperoleh pada jam ke 9 fermentasi, yaitu sebesar $0,158 \%$.
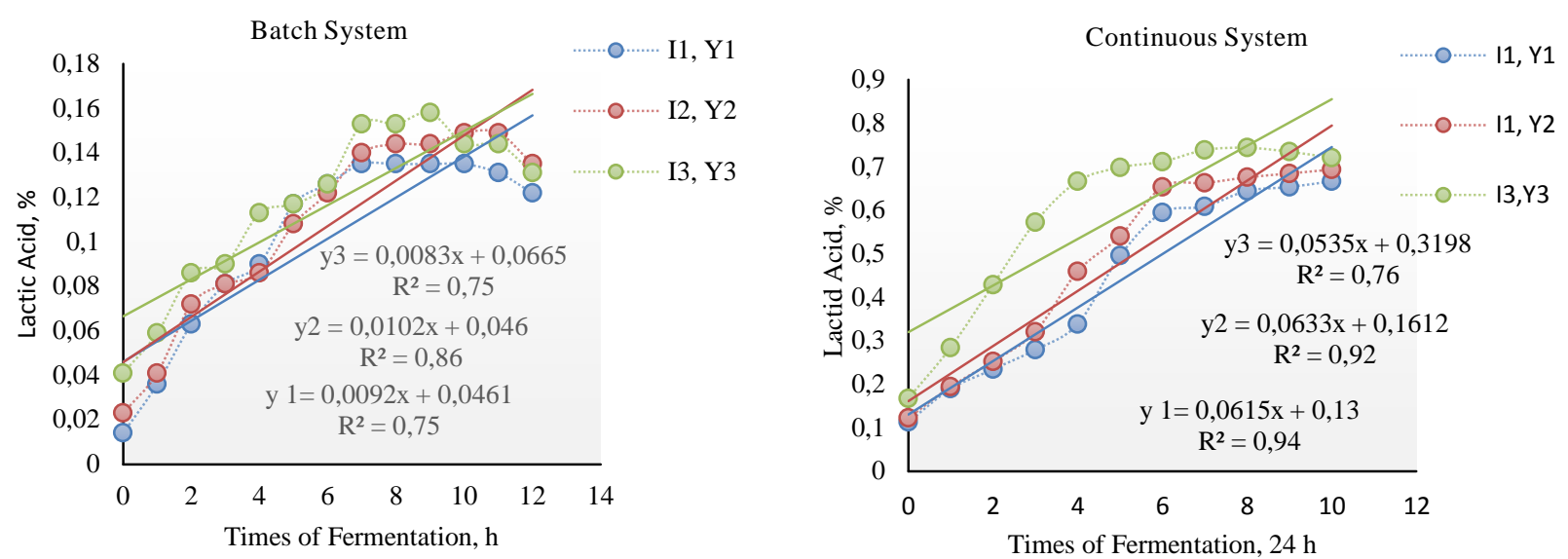

Gambar 3. Total asam laktat dengan variasi konsentrasi inokulum bakteri Lactobacillus acidophilus pada fermentasi sistem batch dan continuous

Gambar 3 memperlihatkan bahwa konsentrasi inokulum bakteri Lactobacillus acidophilus yang paling tinggi menghasilkan asam laktat adalah pada konsentrasi inokulum bakteri Lactobacillus acidophilus $20 \%$ dengan produk asam laktat yang dihasilkan sebesar $0,158 \%$. Pada fermentasi dengan sistem kontinuous konsentrasi inokulum bakteri Lactobacillus acidophilus 5\%, total asam laktat tertinggi diperoleh pada hari ke 10 fermentasi, yaitu sebesar 0,666\%. Pada fermentasi dengan konsentrasi inokulum bakteri Lactobacillus acidophilus $10 \%$, produk asam laktat tertinggi diperoleh pada fermentasi hari ke 10 yaitu sebesar $0,693 \%$. Sedangkan pada fermentasi dengan konsentrasi inokulum $20 \%$, produk asam laktat tertinggi diperoleh pada fermentasi hari ke 8 yaitu sebesar $0,743 \%$, dimana pada hari ke 8 , fermentasi menggunakan konsentrasi 5\% dan 10\% inokulum bakteri Lactobacillus acidophilus hanya mampu menghasilkan asam laktat sebesar $0,644 \%$ dan $0,675 \%$. Menurut [11] proses fermentasi dengan sistem continuous, mikroba akan terus berkembang sampai mencapai keadaan pertumbuhan yang paling optimum. Pertumbuhan pada keadaan ini merupakan pertumbuhan berfase eksponensial. Pertumbuhan ini bisa bertahan jika nutrisi yang diberikan tidak terhenti. Penambahan inokulum akan berbanding lurus dengan kadar asam laktat yang dihasilkan [12].

Hasil analisis regresi selain konsentrasi inokulum, lama fermentasi juga memiliki hubungan yang kuat terhadap konsentrasi asam laktat. Nilai koefisien korelasi untuk perlakuan fermentasi system bacth I1, I2 dan I3 berturut-turut yaitu $\mathrm{R}^{2}=0,75, \mathrm{R}^{2}=0,86$ dan $\mathrm{R}^{2}=0,75$. Sedangkan untuk sistem kontinuous perlakuan I1, I2 dan I3 berturut-turut yaitu $\mathrm{R}^{2}=0,94, \mathrm{R}^{2}=0,92$ dan $\mathrm{R}^{2}=0,76$. Menurut [13], lama fermentasi berpengaruh terhadap konsentrasi asam laktat yang dihasilkan, yaitu dengan bertambahnya waktu fermentasi maka konsentrasi asam laktat yang terbentuk akan semakin meningkat.

\section{Derajat Keasaman}

Nilai $\mathrm{pH}$ awal air kelapa yang digunakan sebagai substrat pada fermentasi sistem batch adalah 5,59. Hasil penelitian menunjukkan bahwa $\mathrm{pH}$ air kelapa pada fermentasi sistem batch menggunakan konsentrasi inokulum 5\%, 10\% dan 20\% mengalami penurunan seiring bertambahnya waktu fermentasi, dimana nilai $\mathrm{pH}$ akhir untuk konsentrasi inokulum 5\%, 10\% dan 20\% masing-masing adalah 4,25; 4,22 dan 4,23. Hasil analisis total asam laktat yang diperoleh dari fermentasi air kelapa menggunakan sistem batch dan continuous menurun seiring meningkatnya konsentrasi inokulum bakteri Lactobacillus acidophilus seperti yang diperlihatkan pada Gambar 4. 

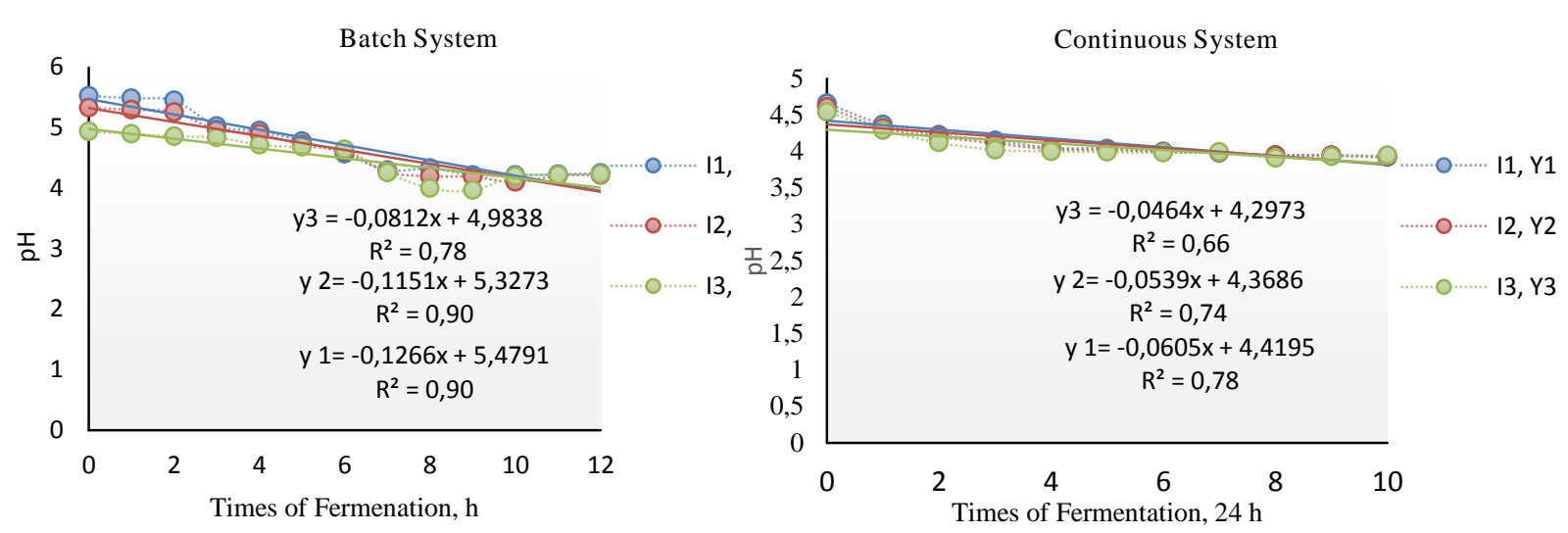

Gambar 4. Derajat keasaman $(\mathrm{pH})$ pada proses fermentasi dengan variasi konsentrasi inokulum bakteri Lactobacillus acidophilus sistem batch dan continuous

Gambar 4 memperlihatkan bahwa selama proses fermentasi nilai pH cenderung menurun seiring lamanya fermentasi. Penurunan nilai $\mathrm{pH}$ ini membuktikan bahwa terjadinya proses fermentasi. [14] menyatakan bahwa penambahan starter pada proses fermentasi dapat menurunkan nilai $\mathrm{pH}$. Konsentarasi bakteri starter akan berbanding terbalik dengan nilai $\mathrm{pH}$ asam laktat yang dihasilkan dari proses fermentasi.

Nilai $\mathrm{pH}$ awal air kelapa yang digunakan sebagai substrat pada fermentasi continuous yaitu 4,78. $\mathrm{pH}$ akhir untuk konsentrasi 5\%, 10\% dan 20\% masing-masing adalah 3,92; 3,93 dan 3,95. Ini menunjukkan bahwa $\mathrm{pH}$ mengalami penurunan atau produk semakin asam. Besar nilai $\mathrm{pH}$ akan mempengaruhi bakteri dalam mengubah subtrak menjadi asam laktat pada proses fermentasi. Menurut [15], bakteri Lactobacillus acidophilus mampu bertahan hidup dalam larutan/lingkungan asam. Bakteri ini mampu hidup pada $\mathrm{pH}$ dibawah 4-5.

Hasil analisis regresi selain konsentrasi inokulum, lama fermentasi juga memiliki hubungan yang kuat terhadap derajat keasaman $(\mathrm{pH})$. Nilai $\mathrm{pH}$ menurun seiring bertambahnya konsentrasi inoculum dan lama fermentasi. Nilai koefisien korelasi untuk perlakuan fermentasi system batch I1, I2 dan I3 berturutturut yaitu $\mathrm{R}^{2}=0,90, \mathrm{R}^{2}=0,90$ dan $\mathrm{R}^{2}=0,78$. Sedangkan untuk system continuous perlakuan I1, I2 dan I3 berturut-turut yaitu $\mathrm{R}^{2}=0,78, \mathrm{R}^{2}=0,74$ dan $\mathrm{R}^{2}=0,66$.

\section{Kadar Glukosa}

Kadar glukosa air kelapa selama proses fermentasi menggunakan sistem batch dan continuous dapat dilihat pada Gambar 5. Pada fermentasi system batch, kadar glukosa air kelapa yang digunakan sebagai substrat adalah sebesar 21,7 g/L. Setelah diinokulasikan dengan Lactobacillus acidophilus dengan konsentrasi 5\%, 10\% dan 20\% pada jam ke 0 kadar glukosa masing-masing menjadi 17,8 g/L, 16,2 g/L dan 14,5 g/L dan kadar glukosa terus menurun hingga jam ke 12, yaitu menjadi $0,75 \mathrm{~g} / \mathrm{L}$ pada fermentasi yang menggunakan 5\% inokulum dan $0 \mathrm{~g} / \mathrm{L}$ pada fermentasi yang menggunakan $10 \%$ dan $20 \%$ inokulum.

Gambar 5 menunjukkan bahwa kadar glukosa menurun seiring lamanya waktu fermentasi. Hal ini disebabkan oleh meningkatnya konsumsi glukosa oleh bakteri Lactobacillus acidophilus pada setiap waktunya. Jadi gula disini sebagai substrak yang digunakan oleh bakteri untuk terus berlangsung proses fermentasi. Bukti terjadinya proses fermentasi dengan menurunnya nilai glukosa. Fermentasi sistem batch menggunakan limbah air kelapa dengan kadar glukosa sebesar 21,7 g/L setelah difermentasi dengan konsentrasi inoculum bakteri Lactobacillus acidophilus 5\%,10\% dan 20\% menghasilkan asam laktat dengan rata-rata sebesar $0,147 \%$ atau $1,77 \mathrm{~g} / \mathrm{L}$ asam laktat.

Fermentasi sistem continuous, kadar glukosa air kelapa yang digunakan sebagai substrat adalah sebesar 1,61 g/L. Sama halnya dengan fermentasi sistem batch, kadar glukosa air kelapa yang difermentasi dengan sistem continuous juga mengalami penurunan setelah dilakukan inokulasi dengan bakteri Lactobacillus acidophilus dengan konsentrasi 5\%, 10\% dan 20\%. Pada awal proses fermentasi atau pada hari ke 0 , kadar glukosa air kelapa yang difermenetasi dengan konsentrasi inokulum 5\%, 10\%, dan 20\% masing-masing adalah 1,42 g/L, 1,41 g/L, dan 1,14 g/L. Namun setelah difermentasi selama 10 hari, kadar glukosa masing-masing menjadi $0 \mathrm{~g} / \mathrm{L}$ atau habis dikonsumsi oleh bakteri. Ref [16] menyatakan bahwa bakteri asam laktat jenis Lactobacillus bulgaricus yang merupakan bakteri homofermentatif mampu mengubah glukosa sebanyak $2-3,5 \mathrm{~g} / \mathrm{L}$ pada tingkat eksponensial serta 8,0 g/L pada tingkat diamnya. Banyaknya kandungan glukosa dalam bahan baku tidak dapat secara mutlak untuk 
menentukan produk asam laktat yang dihasilkan. Akan tetapi, produksi asam laktat masih dipengaruhi oleh faktor-faktor lainnya.
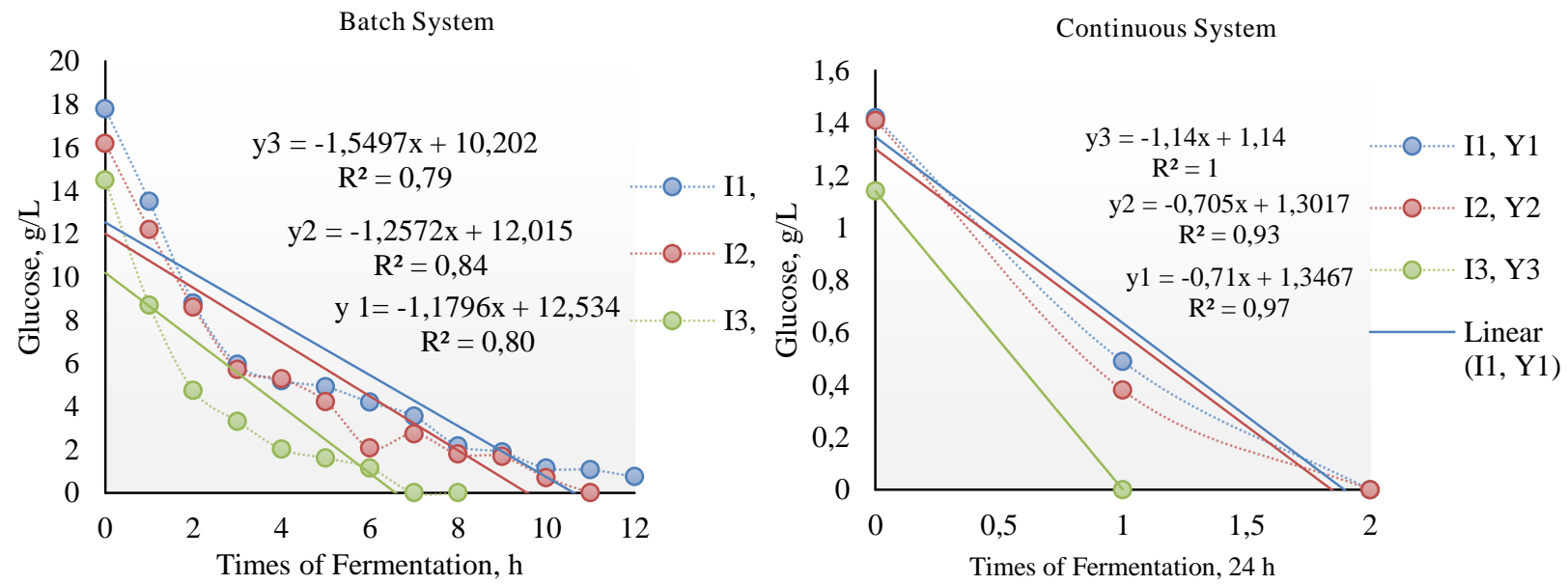

Gambar 5. Kadar glukosa selama fermentasi sistem batch dan continuous

Hasil analisis regresi selain konsentrasi inokulum, lama fermentasi juga memiliki hubungan yang kuat terhadap kadar glukosa. Secara umum kadar glukosa menurun seiring bertambahnya kosentrasi inoculum dan lama fermentasi. Nilai koefisien korelasi untuk perlakuan fermentasi system batch I1, I2 dan $\mathrm{I} 3$ berturut-turut yaitu $\mathrm{R}^{2}=0,80, \mathrm{R}^{2}=0,84$ dan $\mathrm{R}^{2}=0,79$. Sedangkan untuk system continuous perlakuan I1, I2 dan I3 berturut-turut yaitu $\mathrm{R}^{2}=0,97, \mathrm{R}^{2}=0,93$ dan $\mathrm{R}^{2}=1$.

\section{Kandungan TSS, VSS dan TDS}

Total Suspended Solid (TSS)

Pada fermentasi air kelapa dengan sistem batch, kandungan TSS mengalami penurunan hingga akhir proses fermentasi. Penurunan TSS paling besar terjadi pada fermentasi dengan konsentrasi inokulum 20\%, yaitu sebesar 1,5\% dengan kandungan TSS awal sebesar 3,5\% berubah menjadi $2 \%$ setelah difermentasi selama 12 jam. Sedangkan pada fermentasi yang menggunakan inokulum $5 \%$ dan $10 \%$ hanya mengalami penurunan sebesar $1 \%$. Kandungan TSS, VSS dan TDS awal dan akhir proses fermentasi air kelapa dengan sistem batch dan continuous seperti diperlihatkan pada Tabel 2 dan Tabel 3.

Tabel 2. Kandungan TSS, VSS dan TDS awal dan akhir air kelapa pada fermentasi sistem batch

\begin{tabular}{|c|c|c|c|c|c|c|c|c|c|}
\hline \multirow{2}{*}{$\begin{array}{l}\text { Konsentrasi } \\
\text { Inokulum } \\
(\%)\end{array}$} & \multicolumn{2}{|c|}{ TSS (\%) } & \multirow{2}{*}{$\begin{array}{c}\Delta \mathrm{TSS} \\
(\%)\end{array}$} & \multicolumn{2}{|c|}{$\operatorname{VSS}(\%)$} & \multirow{2}{*}{$\begin{array}{c}\Delta \mathrm{VSS} \\
(\%)\end{array}$} & \multicolumn{2}{|c|}{ TDS (mg/L) } & \multirow{2}{*}{$\begin{array}{c}\Delta T D S \\
(\mathrm{mg} / \mathrm{L})\end{array}$} \\
\hline & $\begin{array}{c}0 \text { jam } \\
\text { fermentasi }\end{array}$ & $\begin{array}{l}12 \text { jam } \\
\text { fermentasi }\end{array}$ & & $\begin{array}{c}0 \text { jam } \\
\text { fermentasi }\end{array}$ & $\begin{array}{c}12 \text { jam } \\
\text { fermentasi }\end{array}$ & & $\begin{array}{c}0 \text { jam } \\
\text { fermentasi }\end{array}$ & $\begin{array}{c}12 \text { jam } \\
\text { fermentasi }\end{array}$ & \\
\hline 5 & 4 & 3 & 1 & 75,0 & 42,9 & 32,1 & 4290 & 4250 & 40 \\
\hline 10 & 3 & 2 & 1 & 62,5 & 33,3 & 29,2 & 4280 & 4240 & 40 \\
\hline 20 & 3,5 & 2 & 1.5 & 66,7 & 16,7 & 50 & 4250 & 4210 & 40 \\
\hline
\end{tabular}

Tabel 3. Kandungan TSS, VSS dan TDS awal dan akhir air kelapa pada fermentasi sistem continuous

\begin{tabular}{|c|c|c|c|c|c|c|c|c|c|}
\hline \multirow{2}{*}{$\begin{array}{l}\text { Konsentrasi } \\
\text { Inokulum } \\
(\%)\end{array}$} & \multicolumn{2}{|c|}{ TSS $(\%)$} & \multirow{2}{*}{$\begin{array}{c}\Delta \mathrm{TSS} \\
(\%)\end{array}$} & \multicolumn{2}{|c|}{$\operatorname{VSS}(\%)$} & \multirow{2}{*}{$\begin{array}{c}\Delta \mathrm{VSS} \\
(\%)\end{array}$} & \multicolumn{2}{|c|}{ TDS (mg/L) } & \multirow{2}{*}{$\begin{array}{l}\Delta \mathrm{TDS} \\
(\mathrm{mg} / \mathrm{L})\end{array}$} \\
\hline & $\begin{array}{c}0 \text { hari } \\
\text { fermentasi }\end{array}$ & $\begin{array}{c}10 \text { hari } \\
\text { fermentasi }\end{array}$ & & $\begin{array}{c}0 \text { jam } \\
\text { fermentasi }\end{array}$ & $\begin{array}{c}12 \text { jam } \\
\text { fermentasi }\end{array}$ & & $\begin{array}{c}0 \text { jam } \\
\text { fermentasi }\end{array}$ & $\begin{array}{c}12 \text { jam } \\
\text { fermentasi }\end{array}$ & \\
\hline $5 \%$ & 3 & 2,5 & 0,5 & 71,4 & 66,7 & 4,7 & 4050 & 3960 & 90 \\
\hline $10 \%$ & 3 & 2 & 1 & 80 & 50 & 30 & 4070 & 3940 & 130 \\
\hline $20 \%$ & 3,5 & 2 & 1,5 & 83,3 & 33,3 & 50 & 4230 & 3910 & 320 \\
\hline
\end{tabular}

Terjadinya penurunan dari nilai TSS dapat disebabkan oleh bahan organik yang dikandung dalam bahan mengarami kerusakan pada proses perombakannya. Dalam proses perombakan bahan organik molekul yang lebih besar dipecahkan menjadi molekul yang lebih kecil atau lebih sederhana yang dapat larut dalam air. Selama berlangsungnya proses perombakan ini, padatan tersuspensi selanjutnya 
digunakan pada tahap acidogenesis [17]. Pada fermentasi air kelapa menggunakan sistem batch, kandungan organik mangalami degradasi pada saat proses hidrolisis. Proses hidrolisis kandungan organik pada air kelapa akan diubah menjadi molekul sederhana yang berubah menjadi terlarut, seperti glukosa. Glukosa tersebutlah yang selanjutnya akan digunakan pada tahap acidogenesis sehingga menghasilkan asam laktat.

Fermentasi air kelapa menggunakan sistem continuous Tabel 3, kandungan organik mangalami degradasi pada saat proses hidrolisis. Proses hidrolisis kandungan organic pada air kelapa akan diubah menjadi molekul sederhana yang berubah menjadi terlarut, seperti glukosa. Glukosa tersebutlah yang selanjutnya akan digunakan pada tahap acidogenesis sehingga menghasilkan asam laktat.

\section{Volatile Suspended Solid (VSS)}

VSS merupakan salah satu parameter yang dapat dijadikan rujukan untuk melihat kandungan bahan organik dalam bahan. Tabel 2 memperlihatkan bahwa kandungan VSS mengalami penurunan untuk masing-masing perbedaan konsentarasi inukolum bakteri Lactobacillus acidophilus. Semakin besar konsentrasi inoculum yang diberikan semakin besar penurunan nilai VSS. Hal ini dapat disebabkan oleh perombakan bahan organik yang terdapat dalam air kelapa oleh bakteri Lactobacillus acidophilus.

Hal yang sama juga terjadi pada fermentasi sistem continuous seperti ditunjukkan pada Tabel 3, kandungan VSS air kelapa juga mengalami penurunan. Pada fermentasi dengan konsentrasi inokulum 5\% mengalami penurunan dari kadar awal 71,4\% menjadi $66,7 \%$ dengan penurunan sebesar $4,7 \%$, pada fermentasi dengan konsentrasi inokulum 10\% mengalami penurunan dari kadar awal $80 \%$ menjadi 50\% dengan penurunan sebesar 30\%, sedangkan pada fermentasi dengan konsentrasi inokulum $20 \%$ mengalami penurunan dari kadar awal 83,3\% menjadi 33,3\% dengan penurunan sebesar 50\%.

\section{Total Dissolved Solid (TDS)}

Total dissolved solid atau total padatan terlarut yang terdapat pada air kelapa yang difermentasi dengan sistem batch dapat dilihat pada Tabel 2. Penurunan kandungan TDS pada produk fermentasi terkait dengan adanya mikroorganisme yang mendegradasi bahan organik pada media fermentasi [18]. Penurunan nilai TDS berbanding lurus dengan kandungan bahan organik seperti glukosa.

Fermentasi sistem continuous Tabel 3, Penurunan kandungan TDS juga diakibatkan oleh adanya mikroorganisme yang mendegradasi bahan organik pada media fermentasi [18]. Variasi konsentrasi inokulum menghasilkan nilai TDS yang berbeda. Semakin besar konsentrasi inokulum semakin besar penurunan kandungan nilai TDS baik untuk proses fermentasi secara batch maupun continuous.

\section{Kesimpulan}

Variasi konsentrasi inokulum bakteri Lactobacillus acidophilus 20\% merupakan yang paling optimum menghasilkan total asam laktat untuk sistem batch maupun continuous. Waktu yang paling baik untuk pengambilan produk pada fermentasi sistem batch adalah pada fase eksponensial atau fase stasioner, yaitu pada jam ke 9 fermentasi dimana waktu tersebut merupakan puncak pertumbuhan bakteri Lactobacillus acidophilus. Derajat keasaman $(\mathrm{pH})$ dan glukosa mengalami penurunan seiring bertambahnya waktu fermentasi. Hasil analisis korelasi menunjukkan bahwa variasi inokulum 5\%, $10 \%$ dan $20 \%$ memiliki hubungan yang kuat terhadap produksi asam laktat, penurunan nilai $\mathrm{pH}$ dan penurunan kadar glukosa. Semakin besar konsentrasi inokulum semakin besar pula penurunan kandungan TDS, TSS dan VSS.

\section{Ucapan Terima Kasih}

Puji Syukur Penulis ucapkan kapada Allah Subhanahu wa Ta'ala atas selesainya penelitian ini dan juga terimakasih kepada pihak yang telah membantu diantaranya asisten laboran Teknik Pasca Panen program studi Teknik Pertanian dan asisten laboran analisis pangan Program Studi Teknologi Hasil Pertanian Fakultas Pertanian Unsyiah atas support dan fasilitas yang diberikan pada penelitian ini.

\section{Daftar Pustaka}

[1] E. Widayati., Sutarno dan R. Setyaningsih. "Seleksi isolat bakteri untuk fermentasi asam laktat dari air kelapa varietas rubescent (Cocos nucifera L. Var. rubescent) Biosmart". 4: 32. 2002.

[2] I. R. Pramudyanti., T. Purwoko dan A. Pangastuti. "Pengaruh pengaturan $\mathrm{pH}$ dengan $\mathrm{CaCO} 3$ terhadap produksi asam laktat dari glukosa oleh Rhizopus oryzae". Bioteknologi. 1: 19. 2004.

[3] M.T. Madigan., J.M. Martinko dan J. Parker. "Biology of Microorganisme". Brock. Prentice-Hall Inc. New Jersey. 2000. 
[4] R.S. Bangun. "Pengaruh Fermentasi Bakteri Asam Laktat Terhadap Kadar Protein Susu Kedelai". UNS, Semarang. 2009.

[5] A. Septiani., H. Kusrahayu dan A.M. Legowo. "Pengaruh penambahan susu skim pada proses pembuatan frozen yogurt yang berbahan dasar whey terhadap total asam, $\mathrm{pH}$ dan jumlah bakteri asam laktat". Animal Agriculture. 2: 228-229. 2013.

[6] N. Auliya., R. Fitri, M. Martynis dan Elmi Sundar. "Optimalisasi Pembuatan Bioetanol dari Ampas Umbi Dahlia (Dahlia Spp. L)”. Universitas Bung Hatta, Padang. 2017.

[7] APHA. "Standard Methods for the Examination of Water and Wastewate". American Public Health Association (APHA), American Water Work Association, Water Environment Federation. Washington D. C. 1998.

[8] Darwin., J.J. Cheng, J. Gontupil dan Z. Liu. "Influence of total solid concentration for methane production of cocoa husk co-digested with digested swine manure". Environment and Waste Management. 17: 77. 2016.

[9] D. A. Sari dan Sukanta. "Kajian Kualitas Limbah Cair Secara Anaerobik Melalui COD, BOD, dan TDS: Studi Kasus Pada PT. JKLMN”. Journal of Chemical Process Engineering. 2: 55. 2017.

[10] Riadi, L. Teknologi Fermentasi. Graha Ilmu. Yogyakarta. 2013.

[11] T. Yuwono. "Bioteknologi Pertanian”. Gadjah Mada University Press. Yogyakarta. 2012.

[12] A.J. Franca. "Ebook Fundamental Principles of Bacteriology". Kogakusha Company. Tokyo. 2009.

[13] S. Nining. "Mempelajari pembuatan Yoghurt Susu Kambing". Tesis. Fateta. IPB. Bogor. 1982.

[14] Lengkey, Hendronoto A.W., Siwi, Jan Alex, Balia, Roostita L "The Effect of Various Starter Dosages on Kefir Quality". Lucrari Stiintifice-Seria Zootehnie. 59. 2013.

[15] E. Triana. dan N. Nurhidayat. "Seleksi dan Identifikasi Lactobacillus kandidat probiotik penurun kolesterol berdasarkan analisis sekuen 16s RNA". Biota. 12. 2007.

[16] S. Petry., Furlan S., Crepeau MJ, Cerning J, Dezmazeaud M. "Factors Affecting Exocelluler Polysaccharide Production by Lactobacillus delbueckri subsp". Bulgaricus Grown in a chemically Defined Medium. Appl. EnvironMicrobical. 66: 3427-3431. 2000.

[17] S.N. Chotimah. "Pembuatan Biogas dari Limbah Makanan dengan Variasi dan Suhu Substrat dalam Biodigester Anaerob". Universitas Negeri Sebelas Maret. Surakarta. 2010.

[18] Sugiharto. "Dasar-dasar Pengelolaan Air Limbah". Universitas Indonesia. Jakarta. 1987. 